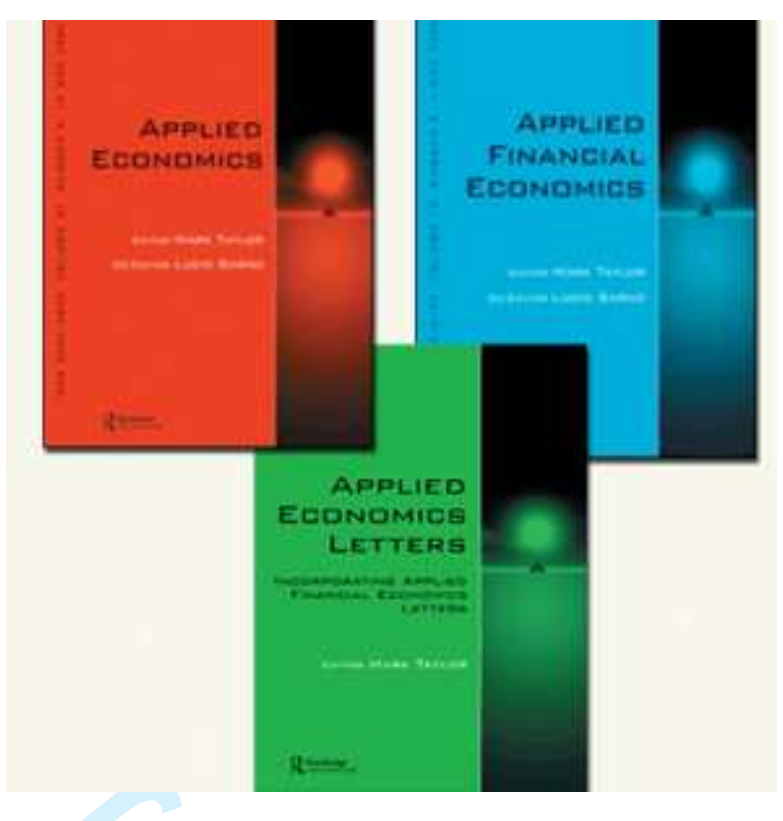

\title{
Smuggling around the World: Evidence from a Structural Equation Model
}

\begin{tabular}{|r|l|}
\hline Journal: & Applied Economics \\
\hline Manuscript ID: & APE-08-0608.R1 \\
\hline Journal Selection: & Applied Economics \\
\hline Author: & 28-Jun-2010 \\
\hline Complete List of Authors: & $\begin{array}{l}\text { Buehn, Andreas; TU Dresden, Faculty of Business and Economics } \\
\text { Farzanegan, Mohammad; TU Dresden, Faculty of Business and } \\
\text { Economics }\end{array}$ \\
\hline JEL Code: & $\begin{array}{l}\text { O17 - Formal, Informal Sectors; Shadow Economy, etc. < O1 - } \\
\text { Economic Development < O - Economic Development, } \\
\text { Technological Change, and Growth, H26 - Tax Evasion < H2 - } \\
\text { Taxation, Subsidies, and Revenue < H - Public Economics, C31 - } \\
\text { Cross-Sectional Models|Spatial Models < C3 - Econometric } \\
\text { Methods: Multiple/Simultaneous Equation Models < C - } \\
\text { Mathematical and Quantitative Methods, H71 - State and Local } \\
\text { Taxation, Subsidies, and Revenue < H7 - State and Local } \\
\text { Government|Intergovernmental Relations < H - Public Economics, } \\
\text { K42 - Illegal Behavior and the Enforcement of Law < K4 - Legal } \\
\text { Procedure, the Legal System, and Illegal Behavior < K - Law and } \\
\text { Economics }\end{array}$ \\
\hline Keywords: & \begin{tabular}{l} 
Smuggling, Illegal trade, Tax burden, Corruption, MIMIC models \\
\hline
\end{tabular} \\
\hline
\end{tabular}




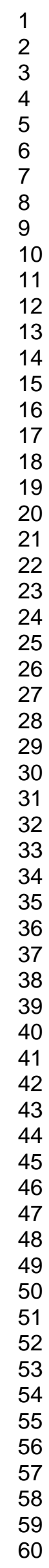

\section{$\$$ ScholaronE \\ Manuscript Central}




\title{
Smuggling around the World: Evidence from a Structural Equation Model
}

\author{
Andreas Buehn* and Mohammad Reza Farzanegan**
}

\begin{abstract}
This paper uses a Multiple Indicators Multiple Causes (MIMIC) model to analyze the determinants of smuggling. The analysis reveals that higher corruption and a lower rule of law encourage smuggling. Tariffs and trade restrictions are important push factors, while a higher black market premium (BMP) discourages smugglers. Based on the MIMIC estimates, we calculate an index of smuggling which provides a ranking for 54 countries. We find that smuggling is rampant in Cameroon, Pakistan, and Kenya while it is least prevalent in Switzerland, Finland, and Sweden.
\end{abstract}

JEL-Classification: O17; H26; C31; H71; K42

Keywords: Smuggling, Illegal trade, Tax burden, Corruption, MIMIC models

\footnotetext{
* Corresponding author: Dresden University of Technology, Faculty of Business and Economics, Chair of Economics, esp. Monetary Economics, 01062 Dresden, E-mail: andreas.buehn@mailbox.tu-dresden.de

** Dresden University of Technology and Centre for European Economic Research (ZEW), Faculty of Business and Economics, Chair of Economics, esp. Public Economics, 01062 Dresden. Email: farzanegan@ zew.de
} 


\title{
Smuggling around the World: Evidence from a Structural Equation Model
}

\begin{abstract}
This paper uses a Multiple Indicators Multiple Causes (MIMIC) model to analyze the determinants of smuggling. The analysis reveals that higher corruption and a lower rule of law encourage smuggling. Tariffs and trade restrictions are important push factors, while a higher black market premium (BMP) discourages smugglers. Based on the MIMIC estimates, we calculate an index of smuggling which provides a ranking for 54 countries. We find that smuggling is rampant in Cameroon, Pakistan, and Kenya while it is least prevalent in Switzerland, Finland, and Sweden.
\end{abstract}

JEL-Classification: O17; H26; C31; H71; K42

Keywords: Smuggling, Illegal trade, Tax burden, Corruption, MIMIC models 


\section{Introduction}

The motivation of being involved in smuggling operations is to make or save money by avoiding taxes/tariffs and/or to circumvent state controls prohibiting the sale of particular goods. Smuggling often involves other crimes such as fraud, fraudulent conversion, bribery, maybe even extortion and violence. Although smuggling has attracted much attention in policy debates, the empirical literature is rather limited. ${ }^{1}$ In this paper we provide an empirical contribution to the literature by applying a structural equation model (SEM) to estimate an index of smuggling for 54 countries around the world.

The hidden and illegal nature of smuggling makes it hard to analyze this economic activity. Estimates of the extent of smuggling in an economy or cross-country comparison often rely on narrow proxies or anecdotal evidence. This paper presents an alternative for the economic analysis of smuggling and contributes to the empirical literature on smuggling in the following two ways: firstly, using a specific form of a SEM with one latent variable, that is a Multiple Indicators Multiple Causes (MIMIC) model, we capture the unobservable nature of smuggling and account for the manifold potential causal and indicator variables of smuggling. ${ }^{2}$ Secondly, we use the MIMIC estimation results to rank the countries according to the extent of smuggling in the economy and compute an index

\footnotetext{
${ }^{1}$ The literature mostly deals with theoretical aspects of the effects of smuggling on social welfare and the economy (see e.g., Bhagwati and Hansen, 1973; Pitt, 1981; Martin and Panagariya, 1984; and Thursby et al., 1991).

${ }^{2}$ MIMIC approaches have been applied to estimate the development of the shadow economy (see, e.g., Dell'Anno and Schneider (2003), Schneider (2005), Alañón and Gómez-Antonio (2005), Dell'Anno and Solomon, and Buehn et al. (2009)) and to corruption (Dreher et al., 2007). Interesting, recent applications of this methodology to smuggling are presented in Farzanegan (2009) and Buehn and Eichler (2009).
} 
of smuggling for 54 countries around the world over the period 1991-1999. This is - to our knowledge - the first comparable estimate of smuggling across countries that can be used in further empirical cross-country analysis, for example, to investigate the smuggling and economic growth nexus.

In general, smuggling includes illegal trade of both legal and illegal goods. ${ }^{3}$ This paper follows Pitt's definition of smuggling: "Traded goods are misweighted, misgraded, misinvoiced or not invoiced at all with or without the cooperation of customs authorities" (Pitt, 1981). Hence, this paper does not deal with the illegal trafficking of human beings such as illegal immigrants and the illegal trade of generally forbidden goods such as illegal drugs. Rather it considers illegal trade of legal goods, often referred to as trade misinvoicing. Given this working definition, the main channel of smuggling is that traders report false amounts of their actual exports or imports to authorities circumventing high taxes, tariffs, and custom duties. But, the incentive to smuggle seems not to be exclusively linked to the level of taxes. For example, in countries with high taxes, such as in the Scandinavian countries, there is little evidence of smuggling. Contrary, in many Eastern European countries, where taxes are much lower, smuggling is more common. This might be due to the observation that countries with a low level of taxes often have less effective systems of border and tax evasion controls and less transparent administrative rules (Merriman et al., 2000). The MIMIC model enables us to analyze whether ineffective administrations and institutions or high tariffs and trade restrictions determine the level of smuggling.

Our analysis reveals that tariffs and trade restrictions are important push factors of smuggling while a higher black market premium (BMP) discourages smugglers. Better

\footnotetext{
${ }^{3}$ Buehn and Eichler (2009) argue that the academic picture of smuggling had been incomplete and consequently distinguish between the smuggling of legal versus illegal goods. 
law enforcement reduces smuggling by increasing the expected costs for illegal traders. A more corrupt society makes it however easier for traders to increase profits by turning to illegal means of trade. The impact of smuggling on the official economy is substantial: it reduces GDP per capita and tax revenues, while it is - as expected - positively correlated to trade misinvoicing. The estimated smuggling index shows that smuggling is less common in the Western European countries but seems to be widespread in Latin America, Asia, and Africa.

The paper is organized as follows. Section 2 presents a short theoretical motivation, a literature review, and the main hypotheses for the empirical analysis. Section 3 introduces the empirical methodology. Section 4 discusses the causes of smuggling and how this activity is reflected in observable indicator variables. Section 5 presents the estimation results and the smuggling index. Section 6 concludes.

\section{Theoretical Motivation}

In most countries, tariffs or import quotas (restrictions on the quantity of imported goods) limit the ability of consumers to choose between foreign or domestic goods. Although financial and capital markets are becoming more integrated, a lot of countries had capital controls until recently, which limited the ability of financial investors to exchange foreign into domestic currency units. These two types of restrictions in international markets make smuggling more attractive. On the one hand, tariffs and trade restrictions create incentives for traders to resort to illegal means of trade such as the smuggling of products or the misinvoicing of exports and imports. On the other hand, capital controls and foreign exchange market restrictions create parallel or black foreign exchange markets and a premium of the parallel over the official exchange rate. This, so called black market premium (BMP) is a very attractive incentive for traders: underinvoicing exports, they can 
realize additional profits by supplying the unrecorded revenues on the black foreign exchange market. However, the existence of a BMP might also be a disincentive for illegal trade. Illegal importers, when underinvoicing imports, have to acquire foreign exchange on the black market for the amount of imports not reported to authorities. In this case, an increasing BMP means increasing costs for illegal importers and thus reduces the incentive to smuggle (see, e.g., De Macedo, 1987).

\subsection{Literature Review}

The existing literature on smuggling consists of two strands. One strand demonstrates that tariffs and restrictions lead to smuggling and misinvoicing in international transactions. The other strand analyzes the welfare effects of smuggling. In their seminal paper, Bhagwati and Hansen (1973) refuted the common argument that smuggling, by evading taxes on trade which are always sub-optimal, improves social welfare. Instead, they found a welfare reducing effect of smuggling when it coexists with legal trade. Introducing a third non-traded good, Sheikh (1974) showed that this coexistence could however be welfare improving. Pitt (1981), in an alternative model of smuggling, demonstrated that the welfare consequences of smuggling are ambiguous. In his model legal and illegal trade do also coexist but, in addition, firms trading illegally use legal trade to camouflage smuggling. This model explains the coexistence of legal trade, illegal trade, and a price disparity defined as the difference between the domestic market price and the tax-inclusive world price of a commodity.

The theoretical literature focusing on the determinants of smuggling confirms the obvious incentives for smuggling, i.e., the existence of trade taxes and restrictions. Several influential contributions proved - see e.g. Bhagwati (1964), Bhagwati and Hansen (1973), and Sheik (1974) - that traders, facing high trade taxes or trade restrictions, resort to 
illegal means of trading such as smuggling and the misinvoicing of exports and imports, i.e., the false declaration of trade documents. Pitt (1981) showed that tariffs cause a price disparity which in turn provides an incentive for illegal imports. Pitt (1984) analyzed the BMP as a determinant for smuggling. He showed that the black market equilibrates the supply and demand for foreign exchange from smuggling activities. Biswas and Marjit (2007) found that import (export) underinvoicing is negatively (positively) correlated to the BMP, since the foreign exchange from unreported transactions is paid (sold) on the black market.

Martin and Panagariya (1984) and Norton (1988) focused on the cost of smuggling and examined the effect of law enforcement. They showed that increasing the probability or cost of confiscation by intensifying law enforcement is a deterrent to smuggling and enables authorities to reduce the extent of smuggling. The reason is that smugglers try to maximize their net gain from smuggling, i.e., the difference between expected revenues and expected costs. The expected costs of smuggling arise from the risk of being caught and punished by authorities and stricter enforcement increases the costs of smuggling making it less attractive for illegal traders. Thursby et al. (1991) investigated the consequences of law enforcement with respect to smuggling for welfare. Because the market price in the presence of smuggling is below the price when all sales are legal, smuggling might improve welfare if the price effect outweighs its cost. Hence, reducing smuggling by increasing law enforcement might come at the cost of reduced welfare of consumers.

Most of the empirical studies use the trade discrepancy which is calculated using balance of payments data as a proxy for smuggling. For example, if import figures reported by the importing country (adjusted for shipping and insurance costs) significantly exceed (fall short of) the export figures reported by the exporting country, these studies 
conclude that import overinvoicing (underinvoicing) takes place in the importing country. Bhagwati (1964) analyzed trade between Turkey and its major trading partners and observed import underinvoicing for machinery and transport equipment. McDonald (1985) analyzed trade in 10 developing countries and found that export underinvoicing is positively correlated with export taxes and the BMP. Pohit and Taneja (2003) analyzed informal trade between India and Bangladesh and found that the potential reduction of transaction costs is a strong motive for smuggling. Fisman and Wei (2004) presented strong empirical evidence that higher tax rates cause tax evasion in the form of trade misinvoicing between China and Hong Kong. Fisman and Wei (2007) studied illicit trade in cultural properties in the United States finding that misinvoicing is highly correlated with the extent of corruption in the exporting country. Berger and Nitsch (2008) confirmed this finding in an extended analysis. Beja (2008) estimated that China's unrecorded trade amounted to $\$ 1.4$ trillion between 2000 and 2005. While Farzanegan (2009) used the MIMIC approach to estimate the size of smuggling in Iran, Buehn and Eichler (2009) applied this methodology to study illegal trade of illegal and legal goods across the U.S.Mexico border. Table 1 presents a summary of the most important findings of the empirical literature on smuggling. 
Table 1. Review of the Empirical Literature on Trade Misinvoicing

\begin{tabular}{|c|c|c|c|}
\hline Study & $\begin{array}{l}\text { Subject of } \\
\text { investigation }\end{array}$ & Approach & Main findings \\
\hline Bhagwati (1964) & $\begin{array}{l}\text { Import underinvoicing } \\
\text { in Turkey }\end{array}$ & $\begin{array}{l}\text { Descriptive analysis of trade from Turkey to } \\
\text { its major trading partners France, Germany, } \\
\text { Italy, Netherlands and the United States. }\end{array}$ & $\begin{array}{l}\text { Import underinvoicing in transport equipment } \\
\text { and machinery }\end{array}$ \\
\hline McDonald (1985) & $\begin{array}{l}\text { Incentives for export } \\
\text { misinvoicing }\end{array}$ & $\begin{array}{l}\text { OLS regressions for } 10 \text { developing } \\
\text { countries; } \\
\text { Dependent variable: trade discrepancies; } \\
\text { Independent variables: BMP and export } \\
\text { taxes }\end{array}$ & $\begin{array}{l}\text { Weak statistical evidence that the BMP and } \\
\text { export taxes explain variations in trade } \\
\text { discrepancies }\end{array}$ \\
\hline $\begin{array}{l}\text { Pohit and Taneja } \\
(2003)\end{array}$ & $\begin{array}{l}\text { Informal trade } \\
\text { between India and } \\
\text { Bangladesh }\end{array}$ & $\begin{array}{l}\text { Direct survey approach encompassing } 100 \\
\text { traders in each country }\end{array}$ & $\begin{array}{l}\text { Anonymous trading transactions characterize } \\
\text { informal trade; motivations are the quick } \\
\text { realization of payments, less paper work, and } \\
\text { procedural delay }\end{array}$ \\
\hline $\begin{array}{l}\text { Fisman and Wei } \\
\text { (2004) }\end{array}$ & $\begin{array}{l}\text { Tax evasion in } \\
\text { Chinese imports from } \\
\text { Hong Kong }\end{array}$ & $\begin{array}{l}\text { Analysis of 2,043 product categories at the } \\
\text { six-digit classification level; } \\
\text { Dependent variable: trade discrepancies } \\
\text { (evasion gap); } \\
\text { Independent variables: tax rate (sum of } \\
\text { tariffs and the VAT), tax on similar } \\
\text { products, tariff exemptions, interaction } \\
\text { terms }\end{array}$ & $\begin{array}{l}\text { One percent increase in the tax rate increases } \\
\text { evasion by three percent; evasion takes place } \\
\text { in two ways: first, trough the reclassification of } \\
\text { high-tax product categories to lower-taxed } \\
\text { categories and second, through the } \\
\text { underinvoicing of imports }\end{array}$ \\
\hline
\end{tabular}


Table 1. Continued.

\begin{tabular}{|c|c|c|c|}
\hline $\begin{array}{l}\text { Fisman and Wei } \\
\text { (2007) }\end{array}$ & $\begin{array}{l}\text { Illegal trade in cultural } \\
\text { properties in the } \\
\text { United States. }\end{array}$ & $\begin{array}{l}\text { Worldwide unbalanced panel for 1996- } \\
2005 \text {; } \\
\text { Dependent variable: trade discrepancies in } \\
\text { cultural object and antiques; } \\
\text { Independent variables: corruption, GDP per } \\
\text { capita }\end{array}$ & $\begin{array}{l}\text { Highly positive correlation between trade } \\
\text { discrepancies and corruption, i.e., more corrupt } \\
\text { countries are more likely to misreport data }\end{array}$ \\
\hline Beja (2008) & $\begin{array}{l}\text { Trade misinvoicing in } \\
\text { China }\end{array}$ & Descriptive analysis of trade discrepancies & $\begin{array}{l}\text { Trade misinvoicing occurs mainly between } \\
\text { Hong Kong and the United States. }\end{array}$ \\
\hline $\begin{array}{l}\text { Berger and Nitsch } \\
(2008)\end{array}$ & $\begin{array}{l}\text { Bilateral trade } \\
\text { discrepancies at the 4- } \\
\text { digit product level }\end{array}$ & $\begin{array}{l}\text { OLS regressions for misinvoicing in } \\
\text { bilateral trade with the United States, } \\
\text { Germany, China, the United Kingdom, and } \\
\text { Japan } \\
\text { Dependent variable: trade discrepancies; } \\
\text { Independent variables: corruption, GDP per } \\
\text { capita, distance measure }\end{array}$ & $\begin{array}{l}\text { Trade discrepancies differ widely across } \\
\text { importers; export underinvoicing is prevalent } \\
\text { in antiques and bulky products; strong positive } \\
\text { correlation with corruption in the source } \\
\text { country }\end{array}$ \\
\hline $\begin{array}{l}\text { Farzanegan } \\
(2009)\end{array}$ & Illegal trade in Iran & $\begin{array}{l}\text { MIMIC approach and trade misinvoicing; } \\
\text { Causes: penalties, BMP, tariffs, GDP per } \\
\text { capita, unemployment rate, openness, } \\
\text { education, institutional quality; } \\
\text { Indicators: government revenues, import } \\
\text { price index, petroleum consumption }\end{array}$ & $\begin{array}{l}\text { Illegal trade is related positively to tariffs and } \\
\text { negatively to fines and the unemployment rate; } \\
\text { Trade openness and a higher BMP encourage } \\
\text { illegal trade while better institutional quality } \\
\text { reduces it; Adverse effects on government } \\
\text { revenues and the import price index; } \\
\text { Smuggling is about } 13 \% \text { of total trade }\end{array}$ \\
\hline
\end{tabular}


Table 1. Continued.

\begin{tabular}{|c|c|c|c|}
\hline $\begin{array}{l}\text { Buehn and } \\
\text { Eichler (2009) }\end{array}$ & $\begin{array}{l}\text { Determinants and } \\
\text { long-term trends of } \\
\text { smuggling across the } \\
\text { U.S.-Mexico border }\end{array}$ & $\begin{array}{l}\text { MIMIC approach for export and import } \\
\text { misinvoicing; } \\
\text { Causes: BMP, real exchange rate, taxes on } \\
\text { income/profits, taxes on international trade } \\
\text { Indicators: errors and omissions, export } \\
\text { misinvoicing, import misinvoicing }\end{array}$ & $\begin{array}{l}\text { Export misinvoicing is positively correlated to } \\
\text { a real peso depreciation and Mexican taxes on } \\
\text { income/profits; } \\
\text { Import misinvoicing is negatively correlated to } \\
\text { a real peso depreciation and Mexican taxes on } \\
\text { income/profits, and positively correlated to } \\
\text { Mexican import tariffs; } \\
\text { Mexico's accession to GATT (1987) and } \\
\text { NAFTA (1994) had a major impact on the } \\
\text { smuggling of legal goods }\end{array}$ \\
\hline
\end{tabular}




\subsection{Main Hypotheses}

Following the theoretical and empirical literature on smuggling we now summarize the main findings of the theoretical literature and formulate our hypotheses regarding the determinants of smuggling. We present the hypotheses about the effects of smuggling section 4.2 where we also discuss the indicators of smuggling.

Facing high tariff rates and trade restrictions, traders often resort to illegal ways of trade, such as the smuggling of products or the misinvoicing of exports and imports. Liberalizing foreign trade and eliminating non-tariff barriers and similar red tapes reduce traders' incentives to smuggle. Also, better law enforcement makes smuggling less attractive/profitable. Of course, if smugglers have been apprehended and their operations exposed, they can facilitate their activities through the bribing of officials to turn a blind eye (Brodie et al., 2000). Thus, more corrupt bureaucrats make it relatively easy for smugglers to get - in exchange for a "small" fee - around certain export restrictions and to avoid punishment when caught. To summarize, our main hypotheses are as follows:

(1) The more trade restrictions, the higher the level of smuggling, ceteris paribus.

(2) The higher tariffs, the higher the level of smuggling, ceteris paribus.

(3) The stricter the law enforcement, the lower the level of smuggling, ceteris paribus.

(4) The higher the level of corruption, the lower the level of smuggling, ceteris paribus.

Because of the two contrasting types of evidence in the literature regarding the effect of the BMP on smuggling, we do not formulate a specific hypothesis about the relationship between the BMP and smuggling. Depending on what kind of smuggling dominates in the countries included in the sample, i.e., import or export smuggling, we expect to observe a negative or positive effect of an increasing BMP on smuggling. 


\section{Empirical Methodology}

SEMs examine relationships between unobservable variables and different observable variables which are classified into causes and indicators. In this paper we investigate a particular alternative of a SEM with one latent endogenous variable which is smuggling. This so-called MIMIC model allows us to analyze the relationship between smuggling and its determinants. Moreover, the key benefits of the MIMIC approach are that it allows modeling of smuggling as a latent variable and dealing with the multiple causes and the multiple effects of smuggling in an economy. ${ }^{4}$

Formally, the MIMIC model consists of two parts: the structural model and the measurement model..$^{5}$ The structural model is given by:

$$
\eta=\gamma^{\prime} x+\varsigma
$$

where $\eta$ is a latent variable, i.e., smuggling, $\boldsymbol{x}^{\prime}=\left(x_{1}, x_{2}, \ldots, x_{q}\right)$ is a $q$ vector and each $x_{i}, i=1, \ldots, q$ is a potential cause of $\eta \cdot \gamma^{\prime}=\left(\gamma_{1}, \gamma_{2}, \ldots, \gamma_{q}\right)$ is a $q$ vector of coefficients in the structural model describing the "causal" relationships between smuggling and its determinants. Thus, $\eta$ is linearly determined by a set of exogenous causes. Since they only partially explain $\eta$, the error term $\varsigma$ represents the unexplained component. The variance of $\varsigma$ is abbreviated by $\psi$ and $\boldsymbol{\Phi}$ is the $(q \times q)$ covariance matrix of the causes $\boldsymbol{x}$.

The measurement model links smuggling to its indicators, i.e., smuggling is expressed in terms of observable variables assuming that the indicators chosen are sound measures of the latent variables. Formally, the measurement model is specified as:

4 Jöreskog, (1970) and Goldberger (1972) introduced structural equation models into economics.

${ }^{5}$ Section 3 briefly explains the MIMIC model. See Bollen (1989) for details. 


$$
\boldsymbol{y}=\lambda \eta+\varepsilon
$$

where $\boldsymbol{y}^{\prime}=\left(y_{1}, y_{2}, \ldots, y_{p}\right)$ is a $p$ vector of several indicator variables of smuggling,

$y_{j}, j=1, \ldots, p . \varepsilon^{\prime}=\left(\varepsilon_{1}, \varepsilon_{2}, \ldots, \varepsilon_{p}\right)$ is a $p$ vector of disturbances where every

$\varepsilon_{j}, j=1, \ldots, p$ is a white noise error term. Their $(p \times p)$ covariance matrix is given by

$\boldsymbol{\Theta}_{\varepsilon}$. The single $\lambda_{j}, j=1, \ldots, p$ in the $p$ vector of regression coefficients $\lambda$ represents the

magnitude of the expected change of the respective indicator for a unit change of

smuggling. Figure 1 provides a general path diagram of a MIMIC model.

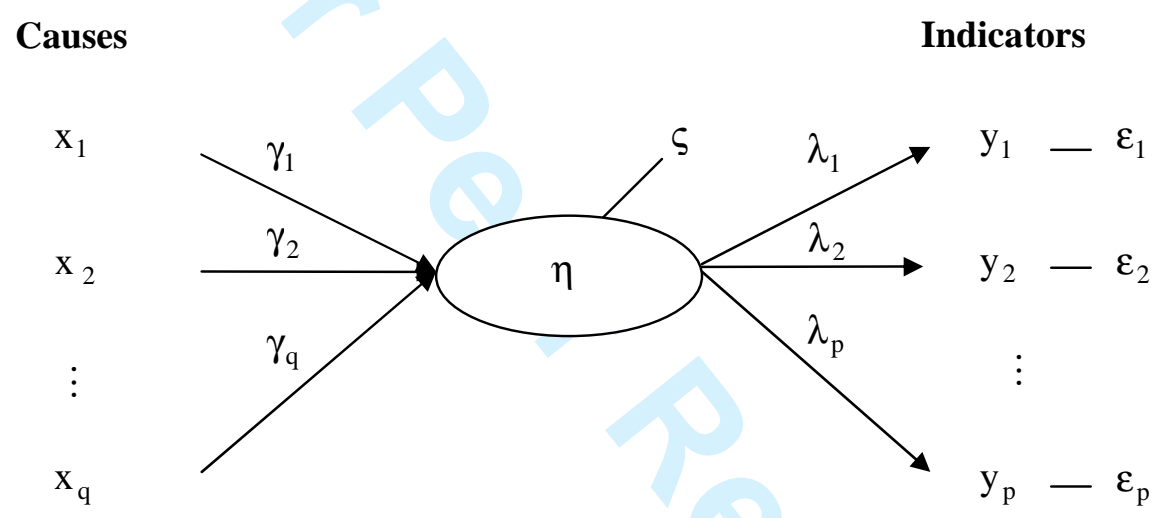

Figure 1. Structure of a MIMIC Model

Substituting equation (1) into (2) yields a reduced form multivariate regression model where the endogenous variables $y_{j}, j=1, \ldots, p$ are the smuggling's indicators and the exogenous variables $x_{i}, i=1, \ldots, q$ its causes. This model is given by:

$$
y=\Pi x+z,
$$

where $\boldsymbol{\Pi}=\lambda \boldsymbol{y}^{\prime}$ is a matrix with rank equal to 1 and $z=\lambda \varsigma+\varepsilon$. The error term $z$ in equation (3) is a $p$ vector of linear combinations of the white noise error terms $\zeta$ and $\varepsilon$ from the structural and the measurement model, i.e., $z \sim(\boldsymbol{0}, \boldsymbol{\Omega})$. The covariance matrix $\boldsymbol{\Omega}$ 
is given as $\operatorname{Cov}(\boldsymbol{z})=\boldsymbol{E}\left[(\lambda \varsigma+\boldsymbol{\varepsilon})(\lambda \varsigma+\boldsymbol{\varepsilon})^{\prime}\right]=\lambda \lambda^{\prime} \psi+\boldsymbol{\Theta}_{\varepsilon}$ and similarly constrained like $\boldsymbol{\Pi}$. Identification and estimation of the MIMIC model therefore requires imposing constraints on the model (Bollen, 1989). A popular constraint imposed in order to achieve identification and produce meaningful estimates of the coefficients is to normalize one of the elements of the vector $\lambda$ to an a priori value (see e.g. Dell'Anno and Schneider, 2009).

Under the assumption that smuggling generates the pattern of covariances among the causes and indicators, the coefficients are estimated by decomposing the MIMIC model's covariance matrix $\Sigma(\boldsymbol{\theta})$ which is a function of the parameters $\lambda, \gamma$ and the covariances contained in $\boldsymbol{\Phi}, \boldsymbol{\Theta}_{\varepsilon}$, and $\psi$. The values for the parameters and covariances are chosen in order to produce an estimate for $\boldsymbol{\Sigma}(\boldsymbol{\theta}), \hat{\boldsymbol{\Sigma}}=\boldsymbol{\Sigma}(\hat{\boldsymbol{\theta}})$, that is as close as possible to the sample covariance matrix $S$ of the observed causes and indicators, i.e., of the $\boldsymbol{x}$ 's and $y^{\prime}$ s. The estimation procedure minimizes the following fitting function:

$$
F=\ln |\boldsymbol{\Sigma}(\boldsymbol{\theta})|+\operatorname{tr}\left[\boldsymbol{S} \boldsymbol{\Sigma}^{-1}(\hat{\boldsymbol{\theta}})\right]-\ln |\boldsymbol{S}|-(p+q)
$$

The first step in the MIMIC model estimation is to confirm the hypothesized relationships between smuggling and its causes as well as indicators. Once these relationships are identified and the parameters estimated, the MIMIC model estimation results are used to calculate a MIMIC score $\eta_{k}$ for each country, $k=1, \ldots, K$, in the sample. The scores for the $K$ countries in the sample make up an index that provides the countries' ranking of smuggling. Before we present these results, the next section discusses causes and indicators of smuggling in detail, presents their empirical implementation, and specifies the empirical MIMIC model of smuggling. 


\section{Causes and Indicators of Smuggling}

\subsection{Causes of Smuggling \\ 4.1.1 Tariff Rates and Trade Restrictions}

As discussed in the literature review, the theoretical and empirical literature shows that tariffs and trade restrictions encourage traders to resort to illegal ways of trade, such as smuggling of products or misinvoicing of exports and imports. To test hypotheses (1) and (2), that higher tariffs and the more trade restrictions encourage smuggling, we use the tariff rate provided by Waczirag and Welch (2003) and a restriction index. For the tariff rate we expect a positive correlation to smuggling. The restriction index is part of the KOF Index of Globalization (Dreher, 2006) and comprises hidden barriers, mean tariff rates, taxes on international trade (per cent of current revenues), and capital account restrictions. This variable ranges from 0 to 100 with higher values of this index indicating a better situation for free trade in a country. Thus, we refer to this index as a lack of trade restrictions index and expect a negative correlation to smuggling, i.e., by liberalizing foreign trade and eliminating non-tariff barriers and similar red tapes, the incentives to smuggle should be reduced. Another alternative to test hypothesis (2) is applying the Openness Index of Penn World Table 6.1 (PWT 2002) (Openness). We thus use this index, instead of the lack of trade restriction index, as a robustness check in some MIMIC model estimations. The expected correlation between Openness and smuggling is negative.

\subsubsection{Rule of Law}

The literature shows that law enforcement is a deterrent to smuggling because higher expected costs, including fines and punishment costs, reduce the net gain of smuggling. The expected costs of smuggling depend on the probability of being caught and punished 
by law enforcing authorities, i.e., on the efficiency of the monitoring system and efforts of the police.

To test hypothesis (3), that better law enforcement reduces the level of smuggling, we use the rule of law index from World Governance Indicators (WGI) (Kaufmann et al., 2007). This index measures the quality of contract enforcement, the police, and the courts and is thus an appropriate proxy for penalties and the perceived costs of smuggling. This index ranges from -2.5 to 2.5 with higher values indicating a stronger police and judiciary system. We thus expect this index to have a negative correlation to smuggling.

\subsubsection{Corruption}

Previous empirical research shows that smuggling is positively correlated to corruption: smuggling is easier in countries with corrupt bureaucracies who are more likely to abuse public power for private gains and allow smugglers this type of escape when caught. ${ }^{6}$ To test hypothesis (4), that more corrupt societies have a higher level of smuggling, we use the corruption variable from the Index of Economic Freedom of the Heritage Foundation (Holmes et al., 2007). Alternatively, and as a robustness check, the measure of corruption from WGI (Kaufmann et al., 2007) is used. Both of these corruption indices are defined in a way that higher values of the index indicate a lower level of corruption. Therefore we refer to each of them as a lack of corruption index and expect a negative effect on smuggling. ${ }^{7}$

\footnotetext{
${ }^{6}$ This is the most general definition of corruption often used in the literature. The World Bank provides a narrower one: “[corruption] distorts the rule of law, weakens a nation's institutional foundation, and severely affects the poor who are already the most disadvantaged members of the society.” (Word Bank, 2009a).

${ }^{7}$ Corruption might also be an indicator of illegal trade in an economy. In fact, smuggling is in
} 


\subsubsection{BMP}

As explained above, a BMP can be an attractive incentive for smuggling. Smugglers can underinvoice exports and exchange the unrecorded revenues on the black foreign exchange market to realize additional profits. But a high BMP can also reduce the incentive to smuggle. This is the case for illegal importers who have to acquire foreign exchange for the amount of imports not reported to authorities on the black market (De Macedo, 1987). Because of the two contrasting types of evidence in the literature we do not formulate a specific hypothesis about the relationship between the BMP and smuggling. Depending on what kind of smuggling dominates in the countries (import/export smuggling), we expect to observe a negative/positive effect of an increasing BMP on smuggling. ${ }^{8}$ The sources for the BMP are Easterly and Sewadeh (2002) and Reinhart and Rogoff (2004).

\subsection{Indicators of Smuggling}

\subsubsection{GDP per capita and Tax Revenues}

Smuggling involves both real and monetary costs. Real costs of smuggling arise from the transfer of production factors such as capital and labor to the illegal and hidden part of the

close connection with bribery and other forms of corruption. Increasing illegal trade may affect the perception of corruption in the society. To consider this issue, we also estimated specification 10 which uses the lack of corruption index as an indicator.

${ }^{8}$ The main analysis examines the effect of the BMP as a causal variable on smuggling. However, it can be argued that changes of the BMP are due to changes in smuggling transactions. Export smugglers supply unreported foreign exchange in the black market and import smugglers demand the foreign exchange in the black market for financing their operations. Thus, in the specifications 8 and 9 we used the BMP as an indicator of smuggling. 
economy. Monetary costs arise from the evasion of taxes and tariffs. Tax revenues are the predominant source of government revenues in most countries. While developed countries rely more on direct taxes such as taxes on income, profits, and capital gains, developing countries depend more on indirect taxes, including taxes on international trade (Askari, 2006, p. 135). This is due to the fact that administrative and implementation costs are lower for indirect taxes than for direct ones. It is thus easier to levy indirect taxes in an environment of lower institutional quality like in developing countries.

Smugglers, by evading legal duties and taxes/tariffs, are an extra burden for the government's budget. Naturally, their activities reduce the government's ability (especially in developing countries as they rely more on indirect taxes) to provide public goods. This may have harmful consequences for the governments' ability to provide public goods. As shown by others (e.g. Loayza, 1996; Johnson et al., 1997), the provision of public goods increases productivity of firms in the official economy. Thus, smuggling by wasting scarce resources - has a negative effect on productivity, development, and economic growth. ${ }^{9}$ Our fifth hypothesis therefore is:

(5) The higher the level of smuggling, the lower foreign trade tax revenues, economic development and growth, ceteris paribus. ${ }^{10}$

To test hypothesis (5) empirically, we use the GDP per capita and a measure of tax revenues as indicators. The source of GDP per capita is Penn World Table (PWT, 2002)

\footnotetext{
${ }^{9}$ See e.g., Norton (1988) and Deardorff and Stolper (1990).

${ }^{10}$ There is also another way to look at the relationship between smuggling and GDP per capita. If countries become richer, they can invest more in monitoring institutions and efficient and transparent trade procedures. Thus, we expect a negative effect of an increasing real GDP per capita on smuggling. We have tested this hypothesis by estimating specification 10 which uses GDP per capita as a causal variable.
} 
and the expected correlation between smuggling and the GDP per capita is negative. Faced with lots of missing data on international trade taxes, we decided to use a broader measure of government revenues instead. Using the total tax revenues from World Bank (2006) as data source, we expect a negative correlation between smuggling and government's total tax revenues. ${ }^{11}$

\subsubsection{Misinvoicing}

Illegal foreign trade transactions are detectable using balance of payment data, in particular partner country trade statistics. A reporting gap or trade data discrepancy occurs if the true value of exports or imports deviates from the amount of exports or imports entrepreneurs report to the authorities. Without smuggling (and measurement error), no systematic reporting gap should exist. It is thus common practice in the literature to use trade discrepancies in official trade data to uncover smuggling. ${ }^{12}$ We follow this approach and expect a positive correlation between trade discrepancies and the true level of smuggling among countries. ${ }^{13}$ Our sixth and final hypothesis therefore is:

${ }^{11}$ Another effect could be that smuggling is accompanied with increased activities in the shadow economy making the size of the shadow economy an appropriate indicator of smuggling. We have thus estimated all specifications of the MIMIC model of smuggling using the size of the shadow economy in the respective country instead of tax revenues as indicator of smuggling. Because the estimation results are qualitatively very similar regarding the causes and other indicators of smuggling, we do not report these estimations in the paper. They are however available upon request.

${ }^{12}$ For recent empirical applications see e.g. Fisman and Wei (2004, 2007), Berger and Nitsch (2008), Farzanegan (2009), and Buehn and Eichler (2009). Makhoul and Otterstrom (1998) provide a comprehensive investigation of statistical discrepancies in the IMF's international trade figures between 1948 and 1994.

${ }^{13}$ We used two similar control groups, namely industrialized economies and the rest of the 
(6) The higher the level of smuggling, the higher the reporting gaps/trade discrepancies in the partner country trade statistics, ceteris paribus.

We use official trade figures to test hypothesis (6), i.e., that a higher reporting gap or trade discrepancy indicate a higher level of smuggling. The data are taken from the Directions of Trade Statistics (DOTS) database of the International Monetary Fund (IMF). In this database, the export figures are in FOB (Free on Board) and imports are in CIF (cost, insurance and freight) prices. In order to make them comparable, we multiply the export figures by an adjustment factor of 1.1 as suggested by the IMF (1993), taking into account transport and insurance costs. More precisely, we used the following two equations to calculate import and export misinvoicing:

Export Misinvoicing $=\mathrm{X}_{\mathrm{i}}-\left(\mathrm{X}_{\mathrm{c}} \cdot \mathrm{CIF}\right.$ factor $)$,

Import Misinvoicing $=\mathrm{M}_{\mathrm{c}}-\left(\mathrm{M}_{\mathrm{i}} \cdot \mathrm{CIF}\right.$ factor $)$,

where $X_{i}$ are imports from a specific country as recorded by industrial economies (or rest of the world), $X_{c}$ are exports as reported by a specific country to industrial economies (or rest of the world), $M_{c}$ are imports as reported by a specific country from industrial economies (or rest of the world), and $\mathrm{M}_{\mathrm{i}}$ are exports of industrial economies (or rest of the world) to a specific country.

While positive values in equation 5 refer to underinvoicing of exports, negative ones refer to overinvoicing of exports by a specific country. In equation 6, positive values refer to overinvoicing of imports and negative ones to import underinvoicing. The total misinvoicing is the sum of absolute amount of import and export misinvoicing. The

world, to calculate trade discrepancies. Relying on the smuggling literature we assume that trade data reported by industrialized countries are accurate. This enables us to interpret discrepancies in trade figures as evidence for misinvoicing. 
definitions and sources of all variables are summarized in Table A.1 in the Appendix.

\subsection{The Empirical MIMIC Model of Smuggling}

In summary, we employ the following main causal variables in the MIMIC approach to smuggling: lack of trade restrictions, tariffs, lack of corruption, BMP, and rule of law. Therefore, the precise specification of the structural equation (1) in the model is:

$$
[\text { Smuggling }]=\left[\gamma_{1}, \gamma_{2}, \gamma_{3}, \gamma_{4}, \gamma_{5}\right] \times\left[\begin{array}{l}
\text { Lack of Trade Restrictions } \\
\text { Tariffs } \\
\text { Lack of Corruption } \\
\text { BMP } \\
\text { Rule of Law }
\end{array}\right]+[\varsigma] \text {. }
$$

On the side of the measurement model and as indicators of smuggling we use the GDP per capita, the trade discrepancy, and tax revenues. Thus, equation (2) of the measurement part of the model results in:

$$
\left[\begin{array}{l}
\text { GDP per capita } \\
\text { Trade Discrepancy } \\
\text { Tax Revenues }
\end{array}\right]=\left[\begin{array}{l}
\lambda_{1} \\
\lambda_{2} \\
\lambda_{3}
\end{array}\right] \times[\text { Smuggling }]+\left[\begin{array}{l}
\varepsilon_{1} \\
\varepsilon_{2} \\
\varepsilon_{3}
\end{array}\right] \text {. }
$$

The concrete path diagram of the empirical MIMIC model is shown in Figure 2. The small squares attached to the arrows indicate the expected signs in the empirical analysis following our hypotheses (1) to (6). 


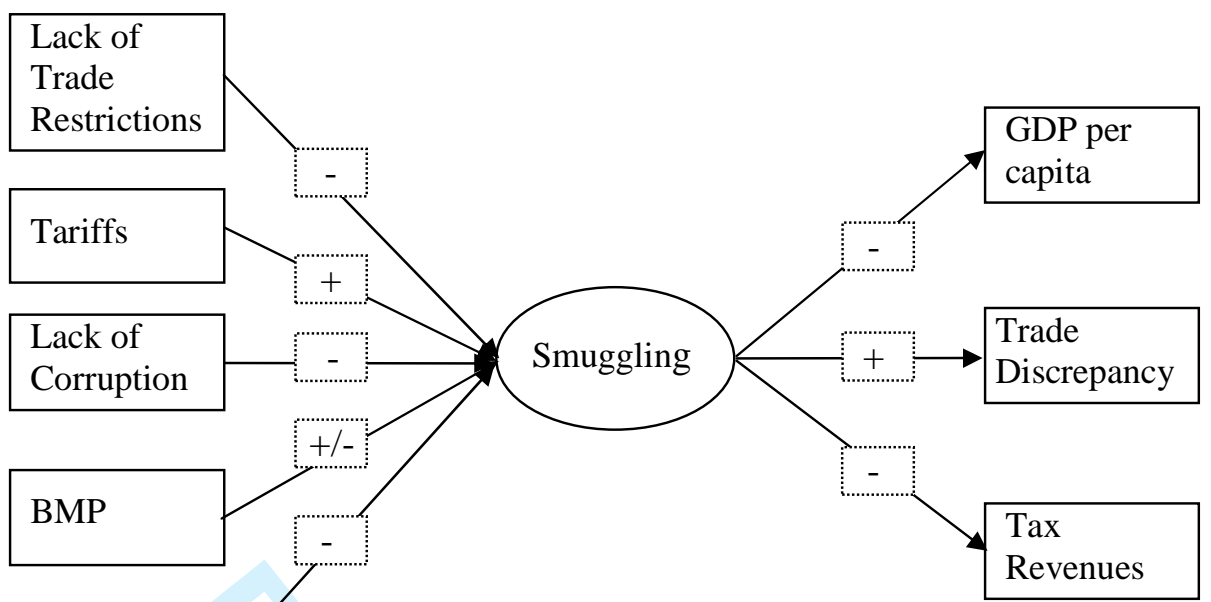

Rule of Law

Figure 2. Path Diagram of the Smuggling MIMIC Model

\section{Results}

\subsection{Estimation Results}

The results of the MIMIC model estimations for smuggling are illustrated in Table 2. We present 10 different MIMIC model specifications. Specification 1 is the baseline estimation. ${ }^{14}$ The estimation period is 1991-1999 and we use the average value of the available data over this period due to data limitations. ${ }^{15}$ We also use different data sources or vary either the set of causes and/or indicators to check the robustness of our results. We report standardized regression coefficients in Table 2, because the interpretation of the relative effects of the causes on the dependent, unobservable variable requires the

\footnotetext{
${ }^{14}$ All calculations have been carried out with LISREL $_{\circledast}$ version 8.80 .

15 The time period was limited to the cut-off of 1999 because of the unavailability of information on some key variables such as the BMP beyond this period. Moreover, some of them - the tariff rate for example - are only available as averages over the estimated period.
} 
1

2

3

4

5

6

7

8

9

10

11

12

13

14

15

16

17

18

19

20

21

22

23

24

25

26

27

28

29

30

31

32

33

34

35

36

37

38

39

40

41

42

43

44

45

46

47

48

49

50

51

52

53

54

55

56

57

58

59

60 examination of the standardized coefficients if the variables are measured on different scales. ${ }^{16}$ The standardized coefficients then indicate - ceteris paribus - the response in standard deviation units of the latent variable for a one standard deviation change in an explanatory, causal variable (Bollen, 1989). In the following we explain the estimation results starting with the causes of smuggling.

\footnotetext{
${ }^{16}$ The standardized coefficients are calculated as $\hat{\gamma}_{j i}^{s}=\hat{\gamma}_{j i} \sqrt{\hat{\sigma}_{i i} / \hat{\sigma}_{j j}}$. Thereby the subscript $\mathrm{s}$ indicates the standardized coefficient; $i$ denotes the causal and $j$ the latent variable. $\hat{\sigma}_{i i}$ and $\hat{\sigma}_{j j}$ are the predicted variances of the ith and $j$ th variable, respectively. 
Table 2. Estimations Results (Standardized Coefficients)

\begin{tabular}{|c|c|c|c|c|c|c|c|c|c|c|}
\hline Specification & 1 & 2 & 3 & 4 & 5 & 6 & 7 & 8 & 9 & 10 \\
\hline \multicolumn{11}{|l|}{ Causes } \\
\hline \multirow[t]{2}{*}{ Lack of trade restrictions } & $-0.16^{*}$ & $-0.16^{*}$ & $-0.18^{*}$ & $-0.18^{*}$ & & $-0.16^{*}$ & $-0.17^{*}$ & $-0.16^{*}$ & & \\
\hline & $(1.69)$ & $(1.71)$ & $(1.90)$ & $(1.88)$ & & (1.68) & $(1.76)$ & $(1.71)$ & & \\
\hline \multirow[t]{2}{*}{ Tariffs } & $0.12^{* *}$ & $0.12^{*}$ & 0.09 & $0.12^{*}$ & $0.18^{* * *}$ & $0.12^{*}$ & $0.11^{*}$ & $0.11^{*}$ & $0.18^{* * *}$ & 0.02 \\
\hline & $(1.96)$ & $(1.95)$ & $(1.47)$ & $(1.94)$ & $(3.36)$ & $(1.85)$ & $(1.76)$ & $(1.81)$ & $(3.19)$ & $(0.25)$ \\
\hline \multirow[t]{2}{*}{ Trade openness } & & & & & 0.04 & 0.03 & & & 0.04 & -0.09 \\
\hline & & & & & $(0.77)$ & $(0.57)$ & & & $(0.76)$ & $(1.11)$ \\
\hline \multirow[t]{2}{*}{ Lack of corruption } & $-0.21^{* * *}$ & $-0.21^{* * *}$ & $-0.26^{* * *}$ & $-0.30^{\mathrm{c})}$ & $-0.23^{* *}$ & $-0.26^{* * *}$ & $-0.26^{* *}$ & $-0.23^{* * *}$ & $-0.25^{* * *}$ & \\
\hline & $(2.55)$ & $(2.58)$ & $(3.21)$ & $(1.54)$ & $(2.73)$ & $(3.20)$ & $(3.15)$ & $(2.90)$ & $(3.09)$ & \\
\hline \multirow[t]{2}{*}{ BMP } & $-0.10^{* *}$ & $-0.10^{* *}$ & $-0.05^{b)}$ & $-0.10^{* *}$ & $-0.10^{* *}$ & & & & & $-0.14^{*}$ \\
\hline & $(2.00)$ & $(1.98)$ & $(1.08)$ & $(1.96)$ & $(2.06)$ & & & & & (1.68) \\
\hline \multirow[t]{2}{*}{ Rule of law } & $-0.64^{* * *}$ & $-0.64^{* * *}$ & $-0.56^{* * *}$ & $-0.51^{* * *}$ & $-0.74^{* * *}$ & $-0.56^{* * *}$ & $-0.56^{* * *}$ & $-0.59^{* * *}$ & $-0.69^{* * *}$ & $-0.36^{*}$ \\
\hline & $(6.10)$ & $(6.08)$ & $(5.66)$ & $(2.39)$ & $(8.36)$ & $(5.65)$ & $(5.60)$ & $(5.89)$ & $(8.34)$ & $(1.67)$ \\
\hline \multirow[t]{2}{*}{ GDP per capita } & & & & & & & & & & $-0.66^{* * *}$ \\
\hline & & & & & & & & & & $(2.94)$ \\
\hline \multicolumn{11}{|l|}{ Indicators } \\
\hline GDP per capita (fixed) & -0.95 & -0.95 & -0.95 & -0.95 & -0.95 & -0.95 & -0.95 & -0.95 & -0.95 & \\
\hline \multirow[t]{2}{*}{ Misinvoicing } & $0.50^{* * *}$ & $0.53^{\mathrm{a}), * * *}$ & $0.51^{* * * *}$ & $0.49^{* * *}$ & $0.49^{* * *}$ & $0.51^{* * *}$ & $0.51^{* * *}$ & $0.51^{* * *}$ & $0.50^{* * *}$ & $0.52^{* * *}$ \\
\hline & (4.17) & $(4.45)$ & $(4.28)$ & $(3.97)$ & $(4.03)$ & $(4.27)$ & $(4.27)$ & $(4.25)$ & (4.11) & (4.13) \\
\hline
\end{tabular}


Table 2. Continued.

\begin{tabular}{|c|c|c|c|c|c|c|c|c|c|c|}
\hline Specification & 1 & 2 & 3 & 4 & 5 & 6 & 7 & 8 & 9 & 10 \\
\hline \multirow[t]{2}{*}{ Tax revenues } & $-0.45^{\text {**** }}$ & $-0.45^{* * *}$ & $-0.43^{* * *}$ & $-0.44^{* * * *}$ & $-0.44^{* * *}$ & $-0.42^{* * *}$ & $-0.42^{* * *}$ & $-0.42^{* * *}$ & $-0.41^{* * *}$ & $-0.45^{* * * *}$ \\
\hline & $(3.64)$ & $(3.64)$ & $(3.39)$ & $(3.48)$ & $(3.55)$ & $(3.35)$ & $(3.37)$ & $(3.35)$ & $(3.25)$ & $(3.50)$ \\
\hline \multirow[t]{2}{*}{ BMP } & & & & & & & & $0.33^{* * *}$ & $0.34^{* * *}$ & \\
\hline & & & & & & & & $(2.57)$ & $(2.60)$ & \\
\hline Lack of corruption (fixed) & & 28 & & & & & & & & -0.86 \\
\hline \multicolumn{11}{|l|}{ Goodness-of-fit statistics } \\
\hline Observations & 54 & 54 & 54 & 54 & 54 & 54 & 54 & 54 & 54 & 54 \\
\hline Degrees of freedom & 21 & 21 & 21 & 21 & 21 & 21 & 15 & 21 & 21 & 21 \\
\hline Chi-square & 20.11 & 19.41 & 11.95 & 21.20 & 19.52 & 12.64 & 11.88 & 29.68 & 29.20 & 17.09 \\
\hline ( $p$-value) & $(0.51)$ & $(0.56)$ & $(0.94)$ & $(0.45)$ & $(0.55)$ & $(0.92)$ & $(0.69)$ & $(0.09)$ & $(0.11)$ & $(0.71)$ \\
\hline RMSEA & 0.00 & 0.00 & 0.00 & 0.01 & 0.00 & 0.00 & 0.00 & 0.09 & 0.09 & 0.00 \\
\hline
\end{tabular}

a) Misinvoicing with control group rest of the world; b) BMP taken from Reinhart and Rogoff (2004); c) Corruption index of WGI

Note: ${ }^{* * *}$ Significance at the $1 \%$ level. ${ }^{* *}$ Significance at the $5 \%$ level. ${ }^{*}$ Significance at the $10 \%$ level. Absolute z-statistics in parentheses. The degrees of freedom are determined by $0.5(\mathrm{p}+\mathrm{q})(\mathrm{p}+\mathrm{q}+1)-\mathrm{t}$; with $\mathrm{p}=$ number of indicators; $\mathrm{q}=$ number of causes; $\mathrm{t}=$ the number for free parameters. If the model fits the data perfectly and the parameter values are known, the sample covariance matrix equals the covariance matrix implied by the model. The null hypothesis of perfect fit corresponds to a $p$-value of 1 . The root mean squared error of approximation (RMSEA) measures the model's fit based on the difference between the estimated and the actual covariance matrix. RMSEA values smaller than 0.05 indicate a good fit (Browne and Cudeck, 1993). 
The lack of trade restrictions index has a negative effect on smuggling in all specifications. As higher values of this index indicate fewer trade restrictions, the observed negative relationship between the lack of trade restriction index and smuggling means that fewer trade restrictions will - as expected - lower the level of smuggling. We also separately controlled for the effect of average tariffs on imports. The results show that tariffs are positively correlated to smuggling. This relationship is statistically significant in all estimated specifications, except for specification 3 and 10. That is, the higher tariffs the more smuggling takes place, ceteris paribus. For example, in specification 1 , a one standard deviation increase in average tariffs increases smuggling by 0.12 standard deviations. Trade openness enters in specifications 5,6 , 9, and 10. Its effect on smuggling is not conclusive. On the one hand one can argue that more openness decreases the incentive for illegal trade, but on the other hand - as Pitt (1981) mentions - legal trade is used by illegal traders to camouflage their illegal activities. However, neither the positive correlation of this variable to smuggling in specifications 5,6 , and 9 nor the negative correlation in specification 10 is statistically significant. In summary, the statistical evidence confirms our hypotheses (1) and (2) that more trade restrictions and higher tariffs increase the level of smuggling. Openness seems not to be an important determinant of smuggling.

The negative and strongly significant impact of the rule of law index is illustrated in all specifications. As explained in subsection 4.1, this index is used to proxy fine rates on smuggling and the quality of the police and the courts in a country. The negative effect of the rule of law on smuggling is stable through different specifications. A one standard deviation increase in this index reduces smuggling by more than 0.50 standard deviations. The statistical evidence thus confirms hypothesis (3). Given the large standardized coefficient of the rule of law it seems that rather the ease to circumvent administrative rules than high tariffs and trade restrictions determine the level of smuggling.

The lack of corruption index shows a consistent and negative effect on smuggling. This 
effect is statistically significant in all specifications, except for specification 4 which uses the corruption index from WGI (Kaufmann et al., 2007). ${ }^{17}$ A one standard deviation increase in the lack of corruption index decreases the level of smuggling by more than 0.20 standard deviations. The statistical evidence thus confirms hypothesis (4) that higher levels of corruption make smuggling easier, ceteris paribus. Since a high level of corruption undermines the rule of law in a society, both variables may depend on each other. To assure that our results are not driven by the possible collinearity between corruption and the rule of law, we additionally estimate baseline specification 1 excluding the measure of corruption. Our results nevertheless remain robust. All remaining causal variables, i.e., the measure of average tariffs, the lack of trade restrictions index, the BMP, and the rule of law as well as all indicators are statistically significant with the theoretically expected sign. We thus conclude that the possible dependency between the rule of law and corruption does not drive the estimation results. $^{18}$

Finally, the BMP shows a stable and significant negative effect on smuggling. This case is highly possible for import smuggling, where smugglers must finance their illegal imports from the black market of exchange. An increasing premium functions like an extra burden for this group of illegal traders. ${ }^{19}$

\footnotetext{
${ }^{17}$ Recall from subsection 4.1 that for both indices lower index values imply a higher level of

${ }^{18}$ The estimated standardized coefficients of the causes (z-statistics) in this robustness specification
} corruption. are as follows: lack of trade restrictions $-0.18^{*}(-1.84)$; average tariffs $0.14^{* *}(2.18)$; BMP $-0.14^{* * * *}(-$ 2.72); rule of law $-0.81^{* * * *}(-9.15)$. For the indicators we estimate: GDP per capita -0.94 (fixed); Misinvoicing $0.49^{* * *}(3.98)$; tax revenues $-0.44^{* * *}(-3.56)$. The goodness of fit statistics point to a good fit: the chi-square is 20.06 , its p-value 0.17 , and the RMSEA 0.08 .

${ }^{19}$ Specification 3 making use of the BMP from Reinhart and Rogoff (2004) does not confirm this effect at any convenient significance level. 
Turning to the indicators, we find fairly consistent results across different specifications. As explained in section 3, one of the coefficients of the indicators has to be normalized. We selected GDP per capita and set the coefficient of this variable to -1 . The reasoning is that smuggling canalizes resources of an economy from the productive, official part to the grabby, unofficial part, hindering the entire use of the economy's potential capacity and reducing economic growth and development. ${ }^{20}$ The second most important indicator of smuggling is the trade discrepancy or trade misinvoicing, respectively. ${ }^{21}$ The standardized coefficient in the various specifications shows that a one standard deviation increase in smuggling increases misinvoicing by about 0.50 standard deviations, ceteris paribus. Trade discrepancies calculated as trade misinvoicing - are a sound indicator variable for smuggling. The statistical evidence thus confirms hypothesis (6).

The last indicator is tax revenues. Smugglers by evading legal tariffs and duties are an extra burden for government budgets. Increasing smuggling by one standard deviation reduces tax revenues by about 0.40 standard deviations. Again, this effect is stable and significant across different specifications supporting hypothesis (5).

While the main analysis examines the effect of the BMP as a causal variable on smuggling, specification 8 and 9 use the BMP as an indicator. In both specifications, we find a positive, statistically significant correlation between smuggling and the BMP. This correlation can occur in the case of import misinvoicing. The higher the level of import underinvoicing the higher the BMP, ceteris paribus, because illegal importers have to acquire foreign exchange on the black market for the amount of imports not reported to authorities. A higher level of

${ }^{20}$ The choice of the indicator for normalization does not affect the results (Bollen, 1989). Typically, one selects the indicator that loads most on the unobservable variable, i.e., GDP per capita in the MIMIC model of smuggling.

${ }^{21}$ In specification 2, we demonstrated the robustness of our result using the rest of the world instead of the industrialized countries as control group for trade misinvoicing. 
import smuggling thus increases the price for black foreign exchange. In specification 10, we use GDP per capita as a cause to test the hypothesis that if countries become richer, they may invest more in monitoring institutions and efficient and transparent trade procedures which reduces smuggling. The empirical evidence supports this hypothesis. The observed correlation between GDP per capita and smuggling is statistically significant negative. That is, the more developed a country the lower the level of smuggling, ceteris paribus.

All estimated specifications show satisfactory goodness-of-fit statistics. The main statistics such as the chi-square and the RMSEA are given in Table 2 while additional goodness-of-fit statistics are presented in Table A. 2 in the Appendix. In order to check the robustness of our results further, we estimate all specifications excluding the 3 highest and lowest ranked countries according to our index of smuggling. ${ }^{22}$ By doing so, we find that the correlations between smuggling and its causes/indicators remain robust. Although the estimated coefficients and z-statistics change slightly, the results are all in all qualitatively identical. As the model fits the data fairly well and the estimation results remain robust, we accept the validity of the estimated MIMIC model for smuggling. We have used the most important determinants of smuggling as causal variables in the empirical analysis. They show the theoretically expected signs and are statistically significant. We thus conclude that the model is suitable to estimate an index of smuggling for 54 countries around the world. This is done in the next subsection.

\subsection{The Smuggling Index}

We use baseline specification 1 to demonstrate the calculation of the smuggling index for the 54 countries in the sample. The smuggling index is calculated by applying the coefficients of

\footnotetext{
${ }^{22}$ Table 3 in section 5.2 presents the country ranking of the calculated index of smuggling. The 3 highest (lowest) ranked countries in this index are Switzerland, Finland, and Sweden (Kenya, Pakistan, and Cameroon). The estimation results are available upon request.
} 
the significant causal variables to the corresponding observed variables. For the numerical example of specification 1 the smuggling index is given as:

$$
\text { Smuggling }=0.12 \cdot x_{1}-0.16 \cdot x_{2}-0.21 \cdot x_{3}-0.10 \cdot x_{4}-0.64 \cdot x_{5}{ }^{23} \text {. }
$$

The higher the amount of the smuggling index the higher is the level of smuggling over the period of 1991-1999 in a particular country. To check the result for its robustness, we also calculate the smuggling index using two other specifications, i.e. specification 5 and 10 . All three indices are presented in Table 3. The ranking of countries corresponds to specification 1 while the third and fourth columns give the countries' ranking according to specification 5 and 10.

Table 3. Ranking of Countries (1991:1999)

\begin{tabular}{llll}
\hline \hline Country & Specification 1 & Specification 5 & Specification 10 \\
\hline Switzerland & $1(-1.574)$ & $1(-1.709)$ & $1(-1.984)$ \\
Finland & $2(-1.453)$ & $2(-1.585)$ & $12(-1.242)$ \\
Sweden & $3(-1.429)$ & $3(-1.559)$ & $7(-1.452)$ \\
Singapore & $4(-1.413)$ & $5(-1.537)$ & $3(-1.609)$ \\
Austria & $5(-1.413)$ & $4(-1.544)$ & $2(-1.629)$ \\
Netherlands & $6(-1.404)$ & $6(-1.534)$ & $4(-1.520)$ \\
Iceland & $7(-1.324)$ & $7(-1.447)$ & $8(-1.437)$ \\
Canada & $8(-1.308)$ & $8(-1.437)$ & $6(-1.507)$ \\
Belgium & $9(-1.190)$ & $9(-1.312)$ & $11(-1.317)$ \\
Australia & $10(-1.175)$ & $10(-1.285)$ & $5(-1.508)$ \\
\hline \hline
\end{tabular}

${ }^{23} x_{1}, x_{2}, x_{3}, x_{4}$, and $x_{5}$ represent tariffs, the lack of trade restriction index, the lack of corruption index, the BMP, and the rule of law, respectively. 
Table 3. Continued

\begin{tabular}{|c|c|c|c|}
\hline France & $11(-1.160)$ & $11(-1.282)$ & $10(-1.331)$ \\
\hline Japan & $12(-1.1)$ & $12(-1.225)$ & $9(-1.426)$ \\
\hline Spain & $13(-0.875)$ & $14(-0.943)$ & $14(-0.828)$ \\
\hline Portugal & $14(-0.874)$ & $13(-0.951)$ & $16(-0.641)$ \\
\hline Italy & $15(-0.729)$ & $15(-0.815)$ & $13(-0.995)$ \\
\hline Estonia & $16(-0.557)$ & $16(-0.507)$ & $21 \quad(-0.045)$ \\
\hline Greece & $17(-0.436)$ & $17(-0.476)$ & $18(-0.285)$ \\
\hline Korea, Rep. & $18(-0.337)$ & $18(-0.412)$ & $20(-0.242)$ \\
\hline Slovenia & $19(-0.304)$ & $20(-0.302)$ & $17(-0.582)$ \\
\hline Malaysia & $20(-0.263)$ & $19(-0.330)$ & $25(0.086)$ \\
\hline Uruguay & $21(-0.175)$ & $21(-0.214)$ & $23(0.042)$ \\
\hline Cyprus & $22(-0.151)$ & $22(-0.187)$ & $15(-0.650)$ \\
\hline Costa Rica & $23(-0.116)$ & $24(-0.135)$ & $26(0.210)$ \\
\hline Mauritius & $24(-0.109)$ & $23(-0.164)$ & $19(-0.259)$ \\
\hline $\begin{array}{l}\text { Trinidad and } \\
\text { Tobago }\end{array}$ & $25(0.028)$ & $25(-0.001)$ & $22(0.018)$ \\
\hline Latvia & $26(0.097)$ & $26(0.118)$ & $28(0.334)$ \\
\hline Croatia & 27 (0.199) & $27(0.338)$ & $27(0.310)$ \\
\hline Jordan & $28(0.331)$ & $28(0.339)$ & $33(0.581)$ \\
\hline Jamaica & $29(0.388)$ & $30(0.429)$ & $37(0.712)$ \\
\hline Panama & $30(0.389)$ & $29(0.364)$ & $31(0.541)$ \\
\hline Tunisia & $31(0.423)$ & $31(0.450)$ & $32(0.542)$ \\
\hline Mexico & $32(0.483)$ & $32(0.474)$ & $35(0.635)$ \\
\hline Turkey & 33 (0.499) & $34(0.512)$ & $34(0.621)$ \\
\hline
\end{tabular}


Table 3. Continued

\begin{tabular}{|c|c|c|c|}
\hline Algeria & $34(0.512)$ & $52(1.228)$ & $24(0.045)$ \\
\hline Ghana & $35(0.539)$ & $33(0.499)$ & $51(1.104)$ \\
\hline Brazil & $36(0.544)$ & $36(0.601)$ & $30(0.494)$ \\
\hline $\begin{array}{l}\text { Egypt, Arab } \\
\text { Republic }\end{array}$ & $37(0.559)$ & $35(0.587)$ & $36(0.672)$ \\
\hline Bulgaria & $38(0.609)$ & $37(0.646)$ & $29(0.485)$ \\
\hline Sri Lanka & $39(0.639)$ & $38(0.657)$ & $41(0.782)$ \\
\hline Philippines & $40(0.678)$ & $39(0.706)$ & $43(0.795)$ \\
\hline Guatemala & $41(0.781)$ & $40(0.796)$ & $49(1.057)$ \\
\hline China & $42(0.784)$ & $44(0.939)$ & $39(0.760)$ \\
\hline Zambia & $43(0.797)$ & $41(0.821)$ & $52(1.163)$ \\
\hline Ecuador & $44(0.837)$ & $42(0.896)$ & $44(0.841)$ \\
\hline Peru & $45(0.850)$ & $43(0.908)$ & $46(0.928)$ \\
\hline Ukraine & $46(0.855)$ & $45(0.958)$ & $42(0.787)$ \\
\hline Nicaragua & $47(0.910)$ & $46(0.996)$ & $47(0.932)$ \\
\hline $\begin{array}{l}\text { Dominican } \\
\text { Republic }\end{array}$ & $48(0.919)$ & $47(0.999)$ & $38(0.744)$ \\
\hline Indonesia & $49(1.005)$ & $48(1.081)$ & $48(0.941)$ \\
\hline Paraguay & $50(1.023)$ & $50(1.121)$ & $45(0.847)$ \\
\hline India & $51(1.029)$ & $49(1.090)$ & $40(0.768)$ \\
\hline Kenya & $52(1.125)$ & $51(1.183)$ & $53(1.273)$ \\
\hline Pakistan & $53(1.407)$ & $53(1.457)$ & $50(1.072)$ \\
\hline Cameroon & $54(1.627)$ & $54(1.698)$ & $54(1.360)$ \\
\hline
\end{tabular}

The ranking of the countries is not surprising, the developing countries being typically reported as countries with higher levels of smuggling. According to specification 1, the 
country least hit by smuggling is Switzerland, followed by Finland, Sweden, Singapore, and Austria. With the exception of Singapore, Canada, Australia, and Japan, only Western European countries are among the top 15. At the bottom of the scale, Cameroon, Pakistan, Kenya, India, and Paraguay are found to be most hit by smuggling. As can be seen, the bottom of the scale is more heterogeneous. Among the 15 countries hit most by smuggling are 6 Latin American and Caribbean countries, 5 Asian countries, 3 African ones, and one country from Eastern Europe. A comparison of the indices calculated according to specification 1,5 , and 10, i.e. column 2, 3, and 4 of Table 3 , shows that the results are robust, although some differences in the ranking exist. For example, Austria has the $5^{\text {th }}$ lowest level of smuggling according to specification 1 but ranks $4^{\text {th }}$ and $2^{\text {nd }}$ according to specification 5 and 10. It can also be seen that for some countries the ranking according to specification 10 is somewhat different compared to specification 1 and 5. This might have to do with the different set of indicators in specification 10. While specification 1 and 5 use GDP per capita as causal variable and the corruption index of the Heritage Foundation as indicator, we reversed this classification in specification 10. Although almost all available evidence suggests that corruption varies strongly inverse with development (see, among others, Mauro, 1995; Paldam, 2003). The estimation results demonstrate that perceived corruption is in fact higher in countries that experience higher levels of smuggling but also that GDP per capita is the slightly better indicator. The differences in the raking between specification $1 / 5$ and 10 are thus not surprising. The chosen three MIMIC model specifications yield nevertheless a similar outcome with respect to the ranking of countries.

To get a better understanding of the regional differences in smuggling, we also calculated the average smuggling index for different regions/country groups of the world which is shown in Table $4 .{ }^{24}$ According to specification 1, smuggling is by far lowest in High income OECD

\footnotetext{
${ }^{24}$ The classification/grouping of countries is based on the World Bank's definition (World Bank, 2009b).
} 
countries, with an average index of -1.167 . The ranking for the other regions is as follows: Eastern Europe (0.150), Asia (0.243), Middle East and North Africa (MENA) (0.362), Latin America and the Caribbean (0.569), and finally Africa (0.668). Within the High-income OECD countries, smuggling is the biggest problem in Greece followed by Italy and Portugal. The countries with the highest level of smuggling in Eastern Europe are the Ukraine and Bulgaria. While in Asia Pakistan and India are the least, Egypt and Algeria rank last in the MENA region. Among the Latin American and Caribbean countries Uruguay and Costa Rica perform best, while Paraguay, the Dominican Republic, and Nicaragua are at the bottom of the scale. Although only a few African countries are in the sample, we conclude that this region of the world is most affected by smuggling. Within this region, smuggling is the biggest problem in Cameroon and Kenya. 
Table 4. Ranking of Countries According to Regions

\begin{tabular}{|c|c|c|c|}
\hline Country & Specification 1 & Specification 5 & Specification 10 \\
\hline \multicolumn{4}{|c|}{ High income OECD members } \\
\hline Switzerland & $1(-1.574)$ & $1(-1.709)$ & $1(-1.984)$ \\
\hline Finland & $2(-1.453)$ & $2(-1.585)$ & $12(-1.242)$ \\
\hline Sweden & $3(-1.429)$ & $3(-1.559)$ & $7(-1.452)$ \\
\hline Austria & $5(-1.413)$ & $4(-1.544)$ & $2(-1.629)$ \\
\hline Netherlands & $6(-1.404)$ & $6(-1.534)$ & $4(-1.520)$ \\
\hline Iceland & $7(-1.324)$ & $7(-1.447)$ & $8(-1.437)$ \\
\hline Canada & $8(-1.308)$ & $8(-1.437)$ & $6(-1.507)$ \\
\hline Belgium & $9(-1.190)$ & $9(-1.312)$ & $11(-1.317)$ \\
\hline Australia & $10(-1.175)$ & $10(-1.285)$ & $5(-1.508)$ \\
\hline France & $11(-1.160)$ & $11(-1.282)$ & $10(-1.331)$ \\
\hline Spain & $13(-0.875)$ & $14(-0.943)$ & $14(-0.828)$ \\
\hline Portugal & $14(-0.874)$ & $13(-0.951)$ & $16(-0.641)$ \\
\hline Italy & $15(-0.729)$ & $15(-0.815)$ & $13(-0.995)$ \\
\hline Greece & $17(-0.436)$ & $17(-0.476)$ & $18(-0.285)$ \\
\hline Average & -1.167 & -1.227 & -1.263 \\
\hline \multicolumn{4}{|l|}{ Eastern Europe } \\
\hline Estonia & $16(-0.557)$ & $16(-0.507)$ & $21(-0.045)$ \\
\hline Slovenia & $19(-0.304)$ & $20(-0.302)$ & $17(-0.582)$ \\
\hline Latvia & $26(0.097)$ & $26(0.118)$ & $28(0.334)$ \\
\hline Croatia & $27(0.199)$ & $27(0.338)$ & $27(0.310)$ \\
\hline Bulgaria & $38(0.609)$ & $37(0.646)$ & $29(0.485)$ \\
\hline
\end{tabular}

Editorial Office, Dept of Economics, Warwick University, Coventry CV4 7AL, UK 
Table 4. Continued

\begin{tabular}{|c|c|c|c|}
\hline Ukraine & $46(0.855)$ & $45(0.958)$ & $42(0.787)$ \\
\hline Average & 0.150 & 0.209 & 0.215 \\
\hline \multicolumn{4}{|l|}{ Asia } \\
\hline Singapore & $4(-1.413)$ & $5(-1.537)$ & $3(-1.609)$ \\
\hline Japan & $12(-1.1)$ & $12(-1.225)$ & $9(-1.426)$ \\
\hline Republic of Korea & $18(-0.337)$ & $18(-0.412)$ & $20(-0.242)$ \\
\hline Malaysia & $20(-0.263)$ & $19(-0.330)$ & $25(0.086)$ \\
\hline Sri Lanka & $39(0.639)$ & $38(0.657)$ & $41(0.782)$ \\
\hline Philippines & $40(0.678)$ & $39(0.706)$ & $43(0.795)$ \\
\hline China & $42(0.784)$ & $44(0.939)$ & $39(0.760)$ \\
\hline Indonesia & $49(1.005)$ & $48(1.081)$ & $48(0.941)$ \\
\hline India & $51(1.029)$ & $49(1.090)$ & $40(0.768)$ \\
\hline Pakistan & $53(1.407)$ & $53(1.457)$ & $50(1.072)$ \\
\hline Average & 0.243 & 0.243 & 0.193 \\
\hline \multicolumn{4}{|l|}{ MENA } \\
\hline Cyprus & $22(-0.151)$ & $22(-0.187)$ & $15(-0.650)$ \\
\hline Jordan & $28(0.331)$ & $28(0.339)$ & $33(0.581)$ \\
\hline Tunisia & $31(0.423)$ & $31(0.450)$ & $32(0.542)$ \\
\hline Turkey & $33(0.499)$ & $34(0.512)$ & $34(0.621)$ \\
\hline Algeria & $34(0.512)$ & $52(1.228)$ & $24(0.045)$ \\
\hline Egypt, Arab Republic & $37(0.559)$ & $35(0.587)$ & $36(0.672)$ \\
\hline Average & 0.362 & 0.488 & 0.301 \\
\hline
\end{tabular}


Table 4. Continued

\begin{tabular}{|c|c|c|c|}
\hline \multicolumn{4}{|c|}{ Latin America and the Caribbean } \\
\hline Uruguay & $21(-0.175)$ & $21(-0.214)$ & $23(0.042)$ \\
\hline Costa Rica & $23(-0.116)$ & $24(-0.135)$ & $26(0.210)$ \\
\hline Trinidad and Tobago & $25(0.028)$ & $25(-0.001)$ & $22(0.018)$ \\
\hline Jamaica & $29(0.388)$ & $30(0.429)$ & $37(0.712)$ \\
\hline Panama & $30(0.389)$ & $29(0.364)$ & $31(0.541)$ \\
\hline Mexico & $32(0.483)$ & $32(0.474)$ & $35(0.635)$ \\
\hline Brazil & $36(0.544)$ & $36(0.601)$ & $30(0.494)$ \\
\hline Guatemala & $41(0.781)$ & $40(0.796)$ & $49(1.057)$ \\
\hline Ecuador & $44(0.837)$ & $42(0.896)$ & $44(0.841)$ \\
\hline Peru & $45(0.850)$ & $43(0.908)$ & $46(0.928)$ \\
\hline Nicaragua & $47(0.910)$ & $46(0.996)$ & $47(0.932)$ \\
\hline Dominican Republic & $48(0.919)$ & $47(0.999)$ & $38(0.744)$ \\
\hline Paraguay & $50(1.023)$ & $50(1.121)$ & $45(0.847)$ \\
\hline Average & 0.569 & 0.603 & 0.665 \\
\hline \multicolumn{4}{|l|}{ Africa } \\
\hline Mauritius & $24(-0.109)$ & $23(-0.164)$ & $19(-0.259)$ \\
\hline Ghana & $35(0.539)$ & $33(0.499)$ & $51(1.104)$ \\
\hline Zambia & 43 (0.797) & $41(0.821)$ & $52(1.163)$ \\
\hline Kenya & $52(1.125)$ & $51(1.183)$ & $53(1.273)$ \\
\hline Cameroon & 54 (1.627) & 54 (1.698) & $54(1.360)$ \\
\hline Average & 0.668 & 0.673 & 0.777 \\
\hline
\end{tabular}

As argued earlier and also demonstrated by others (see, e.g. Fisman and Wei, 2007; Berger and Nitsch, 2008), smuggling often involves other types of criminal and corrupt activities. we 
illustrate the strong positive correlation between smuggling and corruption in Figure 3 by using the specification 1 of the smuggling index calculated in this paper and the corruption perception index of Transparency International (1999) (henceforth, CPI99). As higher levels of the CPI99 represent a lower level of corruption in a particular country, we use its reverse. The reverse of CPI99 displayed on the x-axis ranges from 0 to 9 while the estimated index of smuggling is displayed on the y-axis. Figure 3 shows that countries like Switzerland or Australia not only have a low level of corruption but are also less affected by smuggling. They are amongst the best performing countries according to the smuggling index. Similarly, countries with very high levels of corruption like Cameroon, Kenya, and Pakistan also have very high levels of smuggling. Some exception should be noted. Belgium, for example, has a much lower level of smuggling compared to Slovenia or Estonia but performs worse with respect to corruption. The same holds for example for Croatia where corruption is as high as in the most corrupt countries but smuggling seems to be less of a problem. Nevertheless, despite few exceptions it is obvious from Figure 3 that smuggling and corruption are all in all positively correlated. 


\section{Conclusion}

The smuggling index presented in this paper provides the first ranking of smuggling around the world during the 1990s. While previous research mostly employs trade discrepancies to uncover smuggling in a country, we employ a structural model of smuggling that simultaneously deals with the causes and indicators of smuggling within a unified framework for 54 countries around the world. This approach has some important advantages. First, in contrast to existing empirical studies which use narrow concepts as a proxy of smuggling, the MIMIC approach enables us to use the most relevant factors to explain smuggling. The empirical analysis shows a highly statistically significant influence of the rule of law and of the level of corruption on smuggling. Trade restrictions and tariffs provide incentives for traders to engage into smuggling. The magnitude of the standardized coefficients indicates that rather the inferiority of institutions than high tariffs and trade restrictions drive smuggling, although the latter are also important determinants. The second advantage is that 
the ranking one retrieves across countries is tied to the causal variables that were used to estimate the model. As such, the model produces a cardinal index of smuggling and considers the common criticisms aimed at perception based indices. According to the index of smuggling presented in this paper, Switzerland, the Scandinavian countries Sweden and Finland, the Netherlands, Singapore, and Austria are among the countries with the lowest level of smuggling. Paraguay, India, Kenya, Pakistan, and Cameroon have the highest level.

Of course, one may argue that the estimated model does not capture the extent of smuggling. There are however two ways to test for the validity of a structural model (Bollen, 1989). First, it is necessary to examine the fit of the model. Secondly, variables related to the latent variable in the theoretical literature should have the expected impact. We have dealt with these two validity tests above: all variables show the theoretically expected correlation to smuggling and the various estimated specifications show satisfactory goodness-of-fit statistics.

Some policy conclusions may be drawn. Countries that endeavor to reduce the size of smuggling can strengthen their institutions. Increasing the rule of law and reducing corruption are most suitable to get hold of smuggling. Reducing trade barriers such as tariffs and quotas is another possibility. Although even the countries most committed to free trade still have restrictions. Of course, it has changed for the better since the mid 1990s: average tariffs have become lower and are still getting lower. Moreover, the smuggling index based on the MIMIC approach is likely to be of interest for different user groups. One such group might be the policy-based academic community which evaluates the consequences of smuggling. Since the index derived here gives a cardinal ranking of smuggling across countries, it has the potential to provide reliable estimates of the impact of smuggling. For various nongovernment organizations that make decisions based on the institutional environment of a particular country the MIMIC approach would also be useful. Calculating an index of smuggling as outlined here for different time periods may help them to monitor how 
smuggling - being a potential indicator of the general institutional quality in a particular country - varies over time. Since the method outlined here is based on measurable time variant causes and indicators, this allows measuring a country's performance in controlling smuggling.

Clearly, the MIMIC approach to smuggling presented in this paper is only an additional step in furthering our understanding about smuggling. Depending on data availability, the model can be estimated over different sub-periods to assess how smuggling has changed over time for each country. Another promising avenue for future empirical research on smuggling is the analysis of the impact of economic, political, and institutional reforms such as the implementation of free trade zones or the improvement of institutional quality on smuggling.

\section{References}

Alañón, A. and Gómez-Antonio, M. (2005) Estimating the size of the shadow economy in Spain: a structural model with latent variables, Applied Economics, 37, 1011-1025.

Askari, H. (2006) Middle East oil exporters: what happened to economic development?, Edward Elgar Publishing Limited.

Beja, E.L. (2008) Estimating trade mis-invoicing from China: 2000 - 2005, China \& World Economy, 16, 82-92.

Berger, H. and Nitsch, V. (2008) Gotcha! A profile of smuggling in international trade, CESifo Working Paper No. 2475.

Bhagwati, J. N. (1964) On the Under-invoicing Imports, Bulletin of the Oxford University, Institute of Economics and Statistics, 26, 389-397.

Bhagwati, J.N. and Hansen, B. (1973) A Theoretical Analysis of Smuggling, The Quarterly Journal of Economics, 87(2), 172-187.

Biswas, A.K. and Marjit, S. (2007) Preferential trade and mis-invoicing: Some analytical implications, International Review of Economics \& Finance, 16, 130-138. 
Bollen, K.A. (1989) Structural Equations with Latent Variables, Wiley.

Brodie, N., Doole, J., and Watson, P. (2000) Stealing History: The Illicit Trade in Cultural Material, McDonald Institute for Archaeological Research.

Browne, M.W. and Cudeck, R. (1993) Alternative ways of assessing model fit, in Testing Structural Equation Models (Eds.) K.A. Bollen and J.S. Long, Sage, Newbury Park CA, pp. $445-455$.

Buehn, A. and Eichler, S. (2009) Smuggling illegal versus legal goods across the U.S.-Mexico border: A structural equations model approach, Southern Economic Journal, 76(2), 328350.

Buehn, A., Karmann, A., and Schneider, F. (2009) Shadow economy and do-it-yourself activities: The German case, Journal of Institutional and Theoretical Economics, 165, 700721.

Byrne, B.M. (1998) Structural Equation Modelling with LISREL, PRELIS and SIMPLIS: Basic Concepts, Applications and Programming, Mahwah, NJ: Lawrence Erlbaum Associates.

De Macedo, J.B. (1987) Currency incontrovertibility, trade taxes and smuggling, NBER Working Paper No. 2177.

Deardorff, A. and Stolper, W. (1990) Effects of smuggling under African conditions: a factual, institutional and analytic discussion, Weltwirtschaftliches Archiv, 126(1), 116-41.

Dell'Anno, R. and Schneider, F. (2003) The shadow economy of Italy and other OECD countries: What do we know?, Journal of Public Finance and Public Choice, 21(2-3), 97120.

Dell'Anno, R. and Solomon, O.H. (2008) Shadow economy and unemployment rate in USA: is there a structural relationship? An empirical analysis, Applied Economics, 40, 25372555. 
Dell'Anno, R. and Schneider, F. (2009) A complex approach to estimate the shadow economy: The structural equation modelling, in Coping with the Complexity of Economics (Eds.) M. Faggini and T. Lux (eds.), Springer: Heidelberg, pp. 110-130.

Dreher, A. (2006) Does Globalization Affect Growth? Evidence from a new Index of Globalization, Applied Economics 38(10), 1091-1110, Updated in Dreher, A., Gaston, N. and Martens, P. (2008) Measuring Globalization: Gauging its Consequences, Springer, New York.

Dreher, A., Kotsogiannis, C., and McCorriston, S. (2007) Corruption around the world: Evidence from a structural model, Journal of Comparative Economics, 35, 443-446.

Easterly, W. and Sewadeh, M. (2002) Global Development Network Growth Database, World Bank, Washington, DC.

Farzanegan, M. R. (2009), "Illegal trade in the Iranian economy: Evidence from a structural model," European Journal of Political Economy, 25, 489-507.

Fisman, R. and Wei, S.-J (2004) Tax rates and tax evasion: Evidence from "missing imports" in China, Journal of Political Economy, 112, 471-496.

Fisman, R. and Wei, S.-J. (2007) The smuggling of art, and the art of smuggling: Uncovering the illicit trade in cultural property and antiques, NBER Working Paper No. 13446.

Goldberger, A. (1972) Structural equation methods in the social sciences, Econometrica, 40(6), 979-1001.

Holmes, K.R., Feulner, E.J., and O’Grady, M.A. (2007) 2007 Index of Economic Freedom, Washington, DC.

IMF (1993) A Guide to Direction of Trade Statistics, International Monetary Fund, Washington, DC.

Johnson, S., Kaufmann, D. and Shleifer, A. (1997) The unofficial economy in transition, Brookings Papers on Economic Activity, 2, 159-221.

Jöreskog, K.G. (1970) A general method for analysis of covariance structures, Biometrika, 57, 
239-251.

Kaufmann, D., Kraay, A., and Mastruzzi, M. (2007) Governance Matters VI: Governance Indicators for 1996-2006, World Bank Policy Research Working Paper 4280, The World Bank, Washington, DC.

Loayza, N.V. (1996) The economics of the informal sector: A simple model and some empirical evidence from Latin America, Carnegie-Rochester Conference Series on Public Policy, 45, 129-162.

Makhoul, B. and Otterstrom, S.M. (1998) Exploring the accuracy of international trade statistics, Applied Economics, 30, 1603-1616.

Martin, L. and Panagariya, A. (1984) Smuggling, Trade and Price Disparity: A Crime Theoretic Approach, Journal of International Economics, 17(3-4), 201-217.

Mauro, P. (1995) Corruption and growth, Quarterly Journal of Economics, 110, 681-712.

McDonald, D.C. (1985) Trade data discrepancies and the incentive to smuggle, IMF Staff paper, 4, 668-692.

Merriman, D. Yurekli, A. and Chaloupka, F. (2000) How big is the worldwide cigarettesmuggling problem?, in Tobacco Control in Developing Countries (Eds.) P. Jha and F. J. Chaloupka, Oxford University Press, London, pp. 365-392.

Mulaik, S.A., James, L.R., Van Alstine, J., Bennett, N., Lind, S., and Stilwell, C.D. (1989) Evaluation of goodness-of-fit indices for structural equation models, Psychological Bulletin, 105, 430-445.

Norton, D. (1988) On the economic theory of smuggling, Economica, 55(217), 107-118.

Paldam, M. (2003) The cross-country pattern of corruption: Economics, culture and the seesaw dynamics, European Journal of Political Economy, 18, 215-240.

Pitt, M.M. (1981) Smuggling and price disparity, Journal of International Economics, 11, 447-458.

Pitt, M.M. (1984) Smuggling and the black market for foreign exchange, Journal of 
International Economics, 16, 243-257.

PWT (2002), Heston, A., Summers, R., and Aten, B., Penn World Table Version 6.1, Center for International Comparisons of Production, Income and Prices at the University of Pennsylvania.

Reinhart, C.M. and Rogoff, K.S. (2004) The modern history of exchange rate Arrangements: A reinterpretation, Quarterly Journal of Economics, 69(1), 1-48, Data set available at http://www.wam.umd.edu/ creinhar, Access to the data: 13.05.2008.

Sheikh, M. (1974) Smuggling, protection and welfare, Journal of International Economics, 4(4), 355-64.

Schneider, F. (2005) Shadow economies around the world: what do we really know?, European Journal of Political Economy, 21(3), 598-642.

Thursby, M., Jensen, R. and Thursby, J. (1991) Smuggling, camouflaging, and market structure, Quarterly Journal of Economics, 106(3), 789-814.

Transparency International (1999), available at: http://www.transparency.org/policy_research/surveys_indices/cpi/previous_cpi/1999, accessed May, 17, 2008.

Wacziarg, R.T. and Horn Welch, K. (2003) Trade liberalization and growth: New evidence, NBER Working Paper No. W10152.

World Bank (2006) World Development Indicators, CD-Rom, Washington, DC World Bank (2009a) Anticorruption, http://go.worldbank.org/K6AEEPROC0. World Bank (2009b) World Bank List of Economies, July 2009, Washington, DC. 


\section{Appendix}

Table A.1. Data Sources and Definitions

\begin{tabular}{|c|c|c|}
\hline Name of variable & Definition & Sources \\
\hline \multicolumn{3}{|l|}{ Causes } \\
\hline Tariff burden & Average tariff rate $(\%)$ & $\begin{array}{l}\text { Wacziarg and Welch } \\
\text { (2003). }\end{array}$ \\
\hline Trade restrictions & Index of restrictions. & $\begin{array}{l}\text { Index of globalization, } \\
\text { KOF Swiss Economic } \\
\text { Institute (Dreher, 2006). }\end{array}$ \\
\hline Openness & $\begin{array}{l}\text { Openness index defined as sum of } \\
\text { exports and imports over GDP. }\end{array}$ & PWT (2002) \\
\hline Black market & Difference between the parallel & Easterly and Sewadeh \\
\hline premium & $\begin{array}{l}\text { exchange rate and the official } \\
\text { exchange rate divided by the official } \\
\text { exchange rate (The exchange rate is } \\
\text { defined as number of units of } \\
\text { domestic currency per US dollar.). }\end{array}$ & (2002). \\
\hline Lack of corruption & Based on quantitative data which & 1) Index of Economic \\
\hline & assess the perception of corruption in & Freedom, Heritage \\
\hline & the business environment, including & Foundation (Holmes et \\
\hline & levels of governmental legal, judicial, & al., 2007). \\
\hline & and administrative corruption. & $\begin{array}{l}\text { 2) WGI, World Bank, } \\
\text { (Kaufmann et al., 2007). }\end{array}$ \\
\hline
\end{tabular}


1

2

3

4

5

6

7

8

9

10

11

12

13

14

15

16

17

18

19

20

21

22

23

24

25

26

27

28

29

30

31

32

33

34

35

36

37

38

39

40

41

42

43

44

45

46

47

48

49

50

51

52

53

54

55

56

57

58

59

60

Table A.1. Continued.

\begin{tabular}{lll}
\hline Rule of law & Measure for the extent of agents' & WGI, World Bank, \\
& $\begin{array}{l}\text { confidence in and abidance by the } \\
\text { rules of society, in particular the }\end{array}$ & 2007). \\
& quality of contract enforcement, the & \\
& police, and the courts, as well as the & \\
& likelihood of crime and violence. & \\
\hline Indicators & & \\
\hline Real GDP per & & PWT (2002). \\
capita & & World Bank (2006). \\
Tax revenues & IMF Directions of \\
Trade discrepancy & Calculated according to equation & Trade Statistics \\
& (4.7) and (4.8). & (DOTS). \\
\hline \hline
\end{tabular}


Table A.2. Further Goodness-of-Fit Statistics

\begin{tabular}{|c|c|c|c|c|c|c|c|c|c|c|}
\hline \multirow[t]{2}{*}{ Goodness-of-fit statistics } & \multicolumn{10}{|c|}{ Specification } \\
\hline & 1 & 2 & 3 & 4 & 5 & 6 & 7 & 8 & 9 & 10 \\
\hline AGFI & 0.85 & 0.86 & 0.91 & 0.84 & 0.86 & 0.90 & 0.89 & 0.79 & 0.79 & 0.88 \\
\hline PGFI & 0.53 & 0.53 & 0.55 & 0.53 & 0.53 & 0.55 & 0.50 & 0.51 & 0.51 & 0.56 \\
\hline ECVI & 0.96 & 0.96 & 0.96 & 0.97 & 0.96 & 0.96 & 1.06 & 1.13 & 1.12 & 0.94 \\
\hline ECVI independence model & 8.36 & 8.45 & 7.97 & 8.88 & 5.68 & 8.19 & 7.87 & 8.36 & 5.68 & 5.68 \\
\hline ECVI saturated model & 1.36 & 1.36 & 1.36 & 1.36 & 1.36 & 1.36 & 1.05 & 1.36 & 1.36 & 1.36 \\
\hline AIC & 50.11 & 49.40 & 41.95 & 51.20 & 49.52 & 42.64 & 37.88 & 59.68 & 59.20 & 45.09 \\
\hline AIC independence model & 442.96 & 447.86 & 422.53 & 470.61 & 300.96 & 434.12 & 417.21 & 442.96 & 300.96 & 300.96 \\
\hline AIC saturated model & 72.00 & 72.00 & 72.00 & 72.00 & 72.00 & 72.00 & 56.00 & 72.00 & 72.00 & 72.00 \\
\hline
\end{tabular}

The adjusted goodness-of-fit index (AGFI) and the parsimony goodness-of-fit index show how closely the reproduced covariance matrix comes to the observed covariance of causes and indicators by taking into account the degrees of freedom and the complexity of the model. Values larger than 0.90 and 0.50 for the AGFI and the PGFI indicate a good fit (Mulaik et al., 1989). Another useful indicator for the evaluation of a model's overall fit is the (ECVI). The expected cross validation index (ECVI) measures the discrepancy between the fitted covariance matrix and the expected covariance matrix in another sample of equivalent size. The 


\section{Submitted Manuscript}

ECVI must be compared to the ECVIs of the independence and the saturated model. The fit of the estimated model is acceptable if its ECVI is below the ECVI of both the independent and saturated model (Byrne, 1998). In all estimated specifications the model's Akaike information criterion (AIC) is reasonably smaller than the independent and saturated models AIC also indicating a good fit of the hypothesized MIMIC model of smuggling. 